\title{
GSK buys partner Human Genome Sciences
}

London-based GlaxoSmithKline (GSK) acquired for $\$ 3.6$ billion long-time collaborator Human Genome Sciences (HGS), the developer of Benlysta (belimumab), a human antibody that targets BLyS (B lymphocyte stimulator) approved in 2011 as the first new drug for lupus in almost 50 years (Nat. Biotechnol. $\mathbf{2 9}$, 292, 2011). The partnership, which began in 1993, has generated two other compounds now in late-stage trials at GSK: darapladib, an inhibitor of lipoprotein-associated phospholipase A2 discovered by

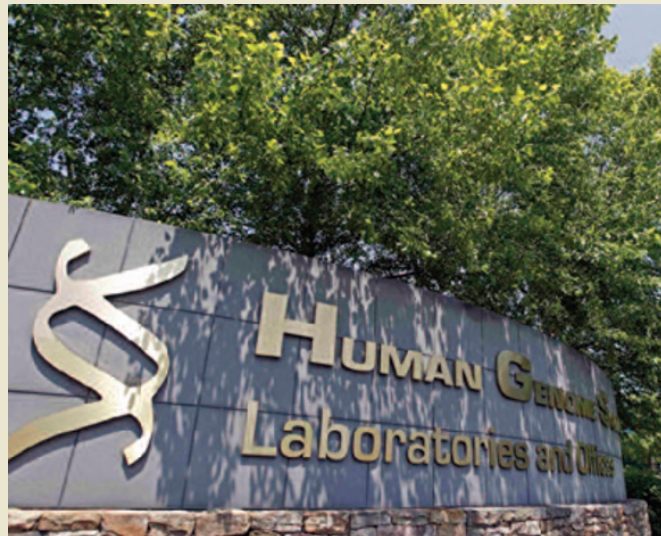

The buyout of HGS continues a run on big biotechs by pharma over the last several years. Source: Human Genome Sciences GSK using HGS technology, for treating cardiovascular diseases including atherosclerosis, and albiglutide, a glucagonlike peptide-1 (GLP-1) receptor antagonist for type 2 diabetes, created by HGS using albumin-fusion technology and licensed to GSK in 2004. GSK initially launched a \$13 per share tender offer for HGS in April 2012. HGS' management advised shareholders to reject that bid, claiming among other things that it did not adequately reflect the value to HGS of the three products, though it also cited synergies GSK would obtain in the buyout and the benefit of HGS' $\$ 2.6$ billion in net operating loss carryforwards and R\&D tax credits. HGS opened the door to competing offers from other companies, but GSK then upped its bid to $\$ 14.25$ per share, or the final $\$ 3.6$-billion price. "It was a foregone conclusion that HGS was going to be acquired by GSK," given the terms of their partnership, says David Brindley of The European Centre for Accelerating Medical Innovations at the University of Oxford. "From an investors' point of view, I'd go as far as to say it was formulaic." Had HGS been as valuable to anyone else, "there's no way that there would not have been a bidding war," he says. With its global marketing infrastructure, GSK may be in better position to maximize the value of Benlysta. With net sales of $\$ 52.3$ million in 2011 and $\$ 31.2$ million in first-quarter 2012, HGS' launch of the drug had fallen below analyst estimates.

If not for GSK's support, Benlysta might never have seen the light of day. The companies began working together in 1993 when GSK (then SmithKline Beecham) committed up to a whopping $\$ 125$ million for rights to HGS' mRNA-based discovery process, among the first industry models for a broad-based genomics approach linking protein discovery with disease. But over the next decade, despite the funding from GSK and a series of large public stock offerings, HGS' own product development efforts foundered. Then, in 2005, GSK became HGS' partner for Benlysta's development, remaining stalwart even after a failed Phase 2 trial a few months later threatened the compound's future and initiating the first of two dramatically successful Phase 3 studies in 2007 (Nat. Biotechnol. 27, 779, 2009).

Mark Ratner, Cambridge, Massachusetts

\section{IN their words}

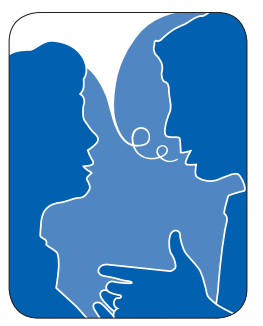

"I never thought this would happen, that the pharma industry would get into ultrapersonalized therapy." The University of Pennsylvania's Carl June after Novartis penned a $\$ 20$ million deal to fund a center at the university for developing chimeric T cell cancer therapy. (Bloomberg Businessweek, 7 August 2012)

"Out of our research in France, we haven't really developed a new molecule in 20 years." Chris Viehbacher, Sanofi's CEO, explains why he is firing workers in Toulouse and Montpellier much to the chagrin of French politicians, labor leaders and researchers. (Bloomberg Businessweek, 9 August 2012)

\section{IN brief}

\section{India's biosimilar regulations}

New guidelines for "similar biologics" launched August 15 will help address local patient access to expensive drugs while serving to attract international manufacturers to India. The Department of Biotechnology and Central Drugs Standard Control Organisation developed the regulatory framework with input from industry and academia. Under the new guidelines, manufacturers must prove similarity to a reference biologic already approved in India or licensed and sold for at least four years in a regulated market. The biosimilar should be comparable to the innovator drug in safety, efficacy and quality as demonstrated by analytical and clinical trials and the preclinical and clinical studies should also be comparative in nature. Approval "without involved clinical trials" is possible if manufacturers prove close similarity to its reference product, and show consistency in production process. Anurag Rathorem at Indian Institute of Technology in New Delhi, who contributed to the guidance says, "We took both the US and European guidelines into consideration while drafting." The guidelines have received a cautious welcome from industry. "The requirement for comparative clinical trials will certainly have an impact on the company's budget allocation," says Geena Malhotra, chief of research at Mumbai-based Cipla.

Recent deals between Mumbai-based Emcure Pharma and Basel-based Roche and between Merck Serono and Dr. Reddy's Laboratories in Hyderabad are a testament to India's growing attractiveness as a biosimilars manufacturing hub. Killugudi Jayaraman

\section{Myriad's patents redux}

The biotech industry breathed a collective sigh of relief with the news that on August 16 the US Court of Appeals for the Federal Court in New York upheld the Myriad patents on BRCA1 and BRCA2. The court came to the same 2-1 decision in 2011, but was asked to revisit the case by the Supreme Court, following its ruling on a related case. (In Mayo Collaborative Sciences v. Prometheus Labs, the Supreme Court found a certain diagnostic to represent a law of nature, and hence not be eligible for patent.) As before, the appeals court reversed two earlier district court findings - that Myriad's DNA test are products of nature, and that a method for screening potential cancer therapeutics employs basic scientific principles. Judge Kimberly Moore wrote that Congress has authorized an "expansive scope of patentable subject matter... and the USPTO [US Patent and Trademark Office] has allowed patents on isolated DNA sequences for decades," saying it is a matter of policy, not for the courts to decide. Dan Vorhaus, editor of The Genomics Law Report, says "Those are the types of extralegal policy-oriented questions that are at the heart of the Myriad litigation and will not be decided by litigation...[but] by policy makers." he says.

Laura DeFrancesco 